\title{
Service Innovation and Customer Choices in the Hospitality Industry
}

\author{
Liana Victorino, University of Utah \\ Rohit Verma, University of Utah \\ Gerhard Plaschka, DePaul University \\ Chekitan Dev, Cornell University
}

Purpose: The purpose of this paper is to understand the impact service innovation has on customers' choices within the hotel and leisure industry. The paper also discusses the influence of the creation of new services on both service development and operational strategy.

Design/methodology/approach: The analysis is based on a national survey of approximately 1,000 travelers in the United States, using a web-based data acquisition approach. The travelers are segmented by reason of travel (business or leisure), and discrete choice analysis is applied to model customer preferences for various hotel service innovations.

Findings: Overall, the study finds that service innovation does matter when guests are selecting a hotel, with type of lodging having the largest impact on a customer's hotel choice. In addition, service innovation is found to have a larger influence on choices when guests are staying at economy hotels rather than mid-range to up-scale hotels. Also, leisure travelers were found to be more influenced by innovative amenities such as childcare programs and in-room kitchenettes than business travelers.

Practical implications: The understanding of customers' choices allows managers to better design their service offerings and formulate corresponding operational strategies around customer needs.

Originality/value: This paper examines the addition of innovation to the hotel service concept and is an excellent tool for managers deciding on which innovations to implement.

Keywords: Innovation, Service industries, Hospitality services, United States of America, Customization

Paper type: Research paper 


\section{Introduction}

Customers, in a number of industries, are constantly bombarded with run-of-the-mill product and service offerings. As a result, customers both desire and more often demand innovative alternatives. In response, many service-oriented firms are striving to integrate novel features into their product-service offerings. Even product-oriented firms have noted the benefits of adding service innovation to their business strategies. For example, during recent years, IBM, a predominantly productoriented firm, generated over half of its total revenue from services. Yet, only 15 percent of IBM's research and development budget was being allocated to services (Fitzgerald, 2005). Realizing this discrepancy, IBM recently realigned its strategy and business plan emphasizing service-based innovations. The new strategy was a resounding success. With one of IBM's innovative service programs adding over $\$ 300$ million to last year's total revenue (Fitzgerald, 2005).

The benefits of service innovation are apparent. What is not as clear is how managers should decide on which innovations to implement. In some cases, innovative service offerings are necessary just to maintain a firm's current market share. This phenomenon suggests " . . that some innovations may merely raise the cost of doing business without a significant economic benefit, other than to preserve current business and without providing a competitive edge ..." (Reid and Sandler, 1992). However, other innovations may enhance service differentiation and induce financial gains. Thus, it is important for managers to implement innovations which are not only desired by customers but also are economically beneficial to the firm (Reid and Sandler, 1992).

Hospitality firms, such as hotels, are an ideal example of a market which could benefit from the implementation of service innovation. First, from a customer's perspective, the hospitality market is perpetually inundated by many similar, often easily substitutable service offerings. This can cause difficulties for hotel managers as they attempt to differentiate an individual hotel from its competitors (Reid and Sandler, 1992). One solution to this challenge may be to offer new and innovative features to customers. Secondly, the hospitality industry is rapidly changing due to accelerations in information technology (Olsen and Connolly, 2000). Managers will need to make proactive changes which focus even more intensely on customer preferences, quality, and technological interfaces in order to stay competitive in such a dynamic environment (Karmarkar, 2004). Thirdly, travelers today do not exhibit, as in past decades, a truly brand loyal behavior. Travelers instead are choosing to patronize hotels that offer the best value proposition under existing budgetary constraints. (Olsen and Connolly, 2000). In order to add value to the guests' experience, hotel managers and marketers must meet the challenge of 
determining which services are preferred by hotel guests (Olsen and Connolly, 2000). Once a manager understands customers' preferences, the challenge then becomes prioritizing those preferences which add the greatest value to the hotel's existing service offering.

The purpose of this study is to explore customer tradeoffs for service innovation. The paper will examine the addition of innovative offerings and its relation to the hotel's core service concept. The service concept encompasses both the "how", in other words, the operations content, and the "what", the marketing content, of service design as well as the integration of the two (Goldstein et al., 2002). In other words, we will examine the innovative service preferences of hotel guests, while also exploring how these preferences align with the strategic intent of the firm. Aligning customer preferences with operational strategy is important because operational constraints make it impossible to implement all options of innovative service offerings. Instead, hotel managers need to develop an understanding of market preferences prior to the addition of new services. This type of knowledge will enable managers to select innovative offerings that are most beneficial to the firm and that will truly have an impact on customer's choices.

The importance of studying innovation's role in services seems obvious. Yet, analysis in service innovation research is lacking in comparison to product innovation research (Chesbrough, 2004). Research which examines the opportunities and risks specific to service innovation as well as the choice sets for system design is needed to further the knowledge in service innovation research (Chesbrough, 2004). In this paper, we provide insight into service innovation by exploring the hotel preferences of both business and leisure travelers. We specifically aim to:

(1) Understand the trade-offs made for business and leisure travelers when choosing a hotel, in terms of innovative hotel market drivers or attributes.

(2) Explore the influence the addition of innovative services has on the design of the core service concept.

(3) Examine the impact of innovative service preferences on operational strategy formulation. We believe that achieving these objectives will be beneficial to academics and practitioners when considering the impact service innovation has on a given firm's core concept. The structure of the paper is organized in the following manner: first, we give a general overview of the previous research regarding the service concept and innovation value. Next we discuss the current hotel innovations that pertain to our study. We then describe our research methods and the application of discrete choice modeling. In addition, we discuss the tradeoffs made by business and leisure travelers when selecting a 
hotel. We conclude by providing insights into service concept development as well as operational strategy formulation.

\section{Background}

\section{The Service Concept}

The wide array of research related to service innovation has primarily focused on the definition of the "service concept" (Goldstein et al., 2002). Edvardsson and Olsson (1996, p. 149) defined the service concept as a "prototype for service, covering the needs of the customer and the design of the service". Previous research has discussed the critical role of the service concept in service design and development (Edvardsson and Olsson, 1996). Furthermore, Goldstein et al. (2002) propose that the service concept is the missing key element in service design research. They suggest that the service concept integrates the "how" and "what" of service design while keeping both the customers' needs and strategic intent of the firm in mind. In other words, the service concept gives a detailed description of what the customer needs and how the organization will deliver the service (Figure 1).

The conceptual background of the "service concept" in operations management literature is similar to "marketing concept". The marketing concept is the key to achieving organizational goals and involves "... determining the needs and wants of target markets and delivering the desired (customer) satisfactions more effectively than competitors ..." (Agarwal et al., 2003, p. 68). Firms that are considered to be market-oriented are presumed to have the capability of understanding their customers better than their competitors. Innovation plays an important role in the marketing concept because it gives the service firm the ability to stay ahead of its competitors through new market offerings. The association between innovation and the market-orientation of a firm was determined to be both positive and significant (Agarwal et al., 2003). In other words, a more market-oriented firm is more likely to consider innovation, which ultimately leads to superior firm performance (Agarwal et al., 2003; Han et al., 1998). The relationship found between innovation and market orientation emphasizes the importance of identifying customers' needs. By understanding customer tradeoffs, service firms will have a better market orientation with a resulting improvement in firm performance. 


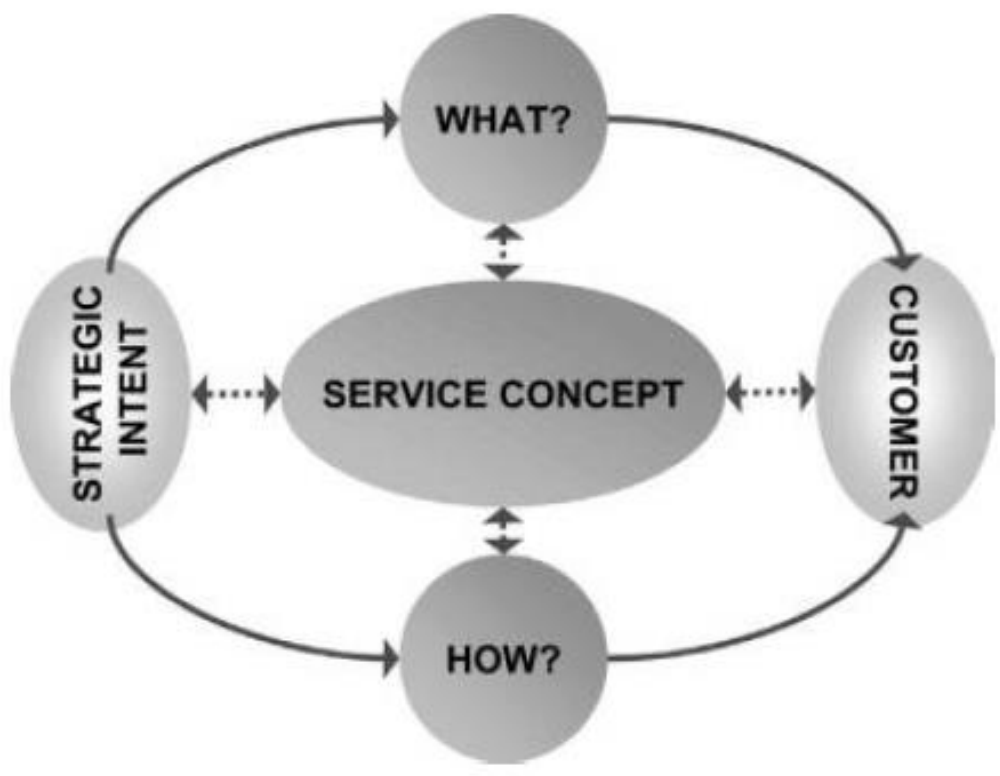

Figure 1. Service concept (Source: Goldstein, Johnston, Duffy, and Rao 2002)

Innovative Value Strategy

Managers when reexamining their existing service offering also need to decide which innovations will create value. For example, managers must ask themselves, which innovations not only deliver additional value to their customers but also are economically viable to the firm. Customer value can be defined as, "the customer's perception of what they want to have happen in a specific-use situation, with the help of a product and service offering in order to accomplish a desired purpose or goal". (Stahl et al., 1999, p. 53). The hospitality industry has an abundance of options which to choose from, when determining which products and services will add value for their customers. For example, a hotel operator can offer various combinations of traditional value drivers such as price, location, and typical hotel amenities, such as pool or work-out facilities. On the other hand, new and innovative value drivers could be offered which include features such as online reservations, in-room high-speed internet access, customization of room décor, and flexible check in/out policies. Before introducing a new service innovation, hotel managers need to assess the value that it will bring to their customers.

A good understanding of value can be gained through empirical research methods, such as customer surveys. Survey research relies heavily on a customer's perception of the functionality, performance, and worth of a supplier's offerings (Anderson and Narus, 1998). By acquiring the vital information of why guests choose to stay at particular hotels, hotel managers are better able to understand the attributes which drive guest's purchasing decisions. Furthermore, understanding the 
guest's needs and desires is invaluable when determining methods for improving company image. A lack of customer preference understanding leads to problems in both product and service design (Schall, 2003). Research shows that the most successful companies are the ones which are fully aware of customer preferences and develop their services in line with targeted market needs (Karmarkar, 2004).

As a competing service firm, it is essential to not only consider the types of innovative attributes to offer but also which operational strategy must be implemented to achieve the firm's goals. Kim and Mauborgne (2000) coined the term "value innovative logic" which differs from a more conventional approach. The conventional objective is to maximize the value of industrial bound offerings while the value innovative goal is to aid the innovative aspect of the service offering (Kim and Mauborgne, 2000). Our research focuses on the value innovation logic for product and service offerings. Therefore, rather than taking a more traditional approach in determining which product and services to offer, an innovative logic approach presents options, “. . in terms of the total solution customers seek, even if that takes the company beyond its industry's traditional offerings" (Kim and Mauborgne, 2000, p. 106).

\section{Innovations in Hospitality Firms}

Hotel Type

The emergence of "boutique" hotels during recent years is an excellent example of an innovative offering in an otherwise standardized industry. The boutique hotel typically features a contemporary or minimalist décor while also offering many additional lifestyle amenities. Hotel guests tend to perceive boutique hotels as a stylish location for which they are willing to pay premium room rates for (Binkley, 1999). Recently, the boutique hotel trend has crossed over into the mid-priced hotel market (Chittium, 2004). Rather than focusing exclusively on the functionality of the hotel product offering, mid-price hotels are beginning to consider the aesthetic appearance of the building's structure and décor (Chittium, 2004). Hotels' guest rooms as well as lobbies are being redesigned in order to stand out amongst the basic hotel offerings. For example, Choice Hotels are planning a new chain of hotels, tentatively named the Diplomat that will feature flat-screen TVs and stylish shelving in its guestrooms (Chittium, 2004). Another higher-priced hotel chain has adopted amenities that are typically associated with boutique hotels while pricing its rooms to be competitive with the mid-priced market. These innovative changes are expected to boost their occupancy rates beyond their rivals (Binkley, 2003). Amenities being offered will include platform beds with no box springs, wire storage racks rather than dressers, plasma television screens, and complimentary wireless DSL access (Binkley, 2003). The 
trendy boutique hotel is an innovation to the traditional hotel experience and an attractive option to consider when designing a hotel service concept, especially when it crosses the traditional industry boundaries into co-branded fashion and jewelry concepts (e.g. the Bulgari-Marriott alliance).

Use of Information Technology

Another example of innovation in hotel services is the use of information technology. One study determined which of the recent technological innovations were most beneficial, least beneficial, and had future benefits for hotels (Reid and Sandler, 1992). The technological innovations that were found to be most beneficial included: a wake up system, electronic door locks, in-room pay-per-view, video cassette players, multiple phone lines, video library, personal computers, voice mail, computer modem connections, video check out, electronic in-room safes, and a software library (Reid and Sandler, 1992). However, it may be impractical for a specific hotel or chain to adopt all available technological amenities due to a lack of operational capabilities or limited resources. Instead, hotels must determine which technological innovations will most benefit their organization.

Aside from customer preferences for technology, the addition of new technological features to a hotel's service concept has distinct phases of adoption (Namasivayam et al., 2000). The technology adoption process includes:

- customer signaling, such as internet booking and in-room modems;

- enabling management, such as management email;

- enabling employees, such as voice mail;

- customer service revenue add-ons, such as ATM and interactive TVs;

- customer service value add-ons, such as internet access and in-room fax machines; and

- wireless technology, such as curbside check-in, voice recognition, and smart cards (Namasivayam et al., 2000).

With the intricacies of implementing technological advances to the service concept, hotel managers need to also take into consideration the adoption process of implementing technology on top of understanding the operational capabilities of the hotel.

\section{Customization of Service}

Customizing the service experience for hotel guests is another means of service innovation. Some examples of service customization include: allowing guests to have flexible check in/out times, personalizing room décor, or having child care options available. Customized options adapt the hotel's 
service offering to each individual guest's preferences. However, customization is not easy to implement due to the operational capabilities of the firm. For example, a flexible check in/out policy could lead to labor scheduling problems. Adding such a policy successfully requires the alignment of hotel's marketing and operational activities. Skinner (1974) provides a product-oriented example of the importance of balancing marketing and operational activities. He suggests that while it may seem profitable to add more products/features to the product mix, it may be too difficult operationally to implement (Skinner, 1974). This dilemma is equally applicable to a service setting, in which adding more services may not operationally be possible.

As we discussed earlier, service innovation is a crucial aspect of a firm's ability to differentiate itself from its competitors and can contribute more to a firm's revenues. Yet, service innovation research is lacking in comparison to product innovation. In this paper, we address this discrepancy by presenting an analysis of hotel travelers' preferences for innovative service offerings and the role innovation plays in service development. The next section describes our research methodology in exploring the innovative choice drivers for business and leisure hotel travelers.

\section{Research Methodology}

\section{Analysis Approach}

An effective method for determining the market-based relative value of various features of a service (e.g. hotels) involves modeling customer preferences in response to experimentally designed service profiles. This approach, commonly known as probabilistic discrete choice analysis (DCA) has been used to model choice processes of decision-makers in a variety of academic disciplines, including marketing, operations management, transportation, urban planning, hospitality, and natural resource economics (Louviere and Timmermans, 1990; Pullman and Moore, 1999; Verma et al., 1999; Verma et al., 2001; Verma et al., 2004).

Statistical models (e.g. Multinomial logit (MNL) models, nested logit models), developed from a DCA study, link service attributes to customer preferences. Therefore by describing a service in terms of appropriate attributes, DCA can be used to predict relative market impact of various service offerings (Danaher, 1997). Recent papers by Verma et al. (1999) and Verma et al. (2002) review DCA literature and provide guidelines for designing and conducting DCA studies of services. Rather than repeating here what has already been detailed in various publications, we only briefly describe the DCA method. 
Discrete choice experiments involve careful design of service profiles, in this case, a specific hotel and choice sets (a number of service alternatives) in which two or more service alternatives are offered to decision-makers and they are asked to evaluate the options and choose one (or none). Each subject in a DCA experiment typically receives several choice sets to evaluate (e.g. 8-32 sets) with two or more hypothetical services to choose from in each set. The design of the experiment is under the control of the researcher, and consequently, the decision-makers' choices (dependent variable) are a function of the attributes of each alternative, personal characteristics of the respondents, and unobserved effects captured by the random component (e.g. unobserved heterogeneity or omitted factors). For a detailed theoretical and statistical background of DCA please refer to Ben-Akiva and Lerman (1991), Louviere et al. (2001) and McFadden (1986).

DCA applications based on choice experiments typically involve the following steps:

- identification of attributes;

- specification of attribute levels;

- experimental design;

- presentation of alternatives to respondents; and

- estimation of the choice model.

Past studies have shown that in general, the market share predictions generated from the statistical models (e.g. MNL) based on DCA are extremely accurate (Ben-Akiva and Lerman, 1991; Louviere et al., 2001). Subsequently we describe our implementation of DCA within the context of business and leisure hotel travelers in the US.

Hotel Attributes and Experimental Design

Prior to finalizing the experimental attributes and levels with the discrete choice customer survey, we conducted extensive qualitative research (Verma et al., 1999). We interviewed managers from economy, mid-range and upscale hotels and several business and leisure hotel customers. Based on qualitative data and a review of academic and practitioner's literature on the topic, we identified five broad constructs of hotel attributes to be varied in discrete choice experiments. They are - hotel type; price; loyalty/frequent user programs; eating options; office facilities and technology options; customization options; and hotel amenities. Each of these constructs was further expanded into attributes (each with two or more levels). However, in this paper we will only focus on the innovative constructs: hotel type, technology, and customization for ease of understanding and clarity. Each of 
these constructs is considered to be innovative because each involves offering services which are not traditional to the industry.

The "hotel type" construct consisted of three attributes: economy, midrange, and upscale. Each attribute was represented by four of the six experimental levels: motel, bed and breakfast inn, independent boutique hotel, standardized hotel affiliated/operated by recognized chain, boutique hotel operated by a recognized chain, and convention style hotel. The "technology" construct was described by three attributes: internet access in room (none, free, $\$ 5$ or 10/day), business center (not available; full-service and centrally located; multiple business kiosks, in-room printer, fax, etc.), and availability of internet reservations (yes, no). The last construct, customization, includes different alternatives which match a person's life-style. Customization was described by five attributes: ability to bring small pets to room (yes, no), availability of flexible check-in/check-out times (yes, no), ability to personalize in-room décor (yes, no), childcare (not available, fee-based nanny and/or kids club for infants and up to 12 years old kids), and in-room kitchen facilities (none, coffeemaker, microwave, refrigerator, and fullkitchenette). Table I describes the innovative attributes and their corresponding experimental levels.

After finalizing the list of attributes and their experimental levels, we designed 64 orthogonal profiles that allowed us to reliably estimate the main effects of all the hotel attributes described above (Verma et al., 1999). To enhance the realism of the task, a full-profile approach was used in presenting the choice sets (Green and Srinivasan, 1990), i.e. each profile shown to the respondents simultaneously described some combination of all the attributes. Within the actual survey three hotel profiles (one economy, one mid-range and one upscale) were shown to respondents at the same time and they were asked to choose one hotel (or neither) which varied from each other on numerous attributes simultaneously. Each respondent evaluated eight hotel choice-sets. In addition to the hotel choice task, the survey instrument included several questions about respondents' past hotel visits as well as demographics.

We pre-tested the survey with 25 randomly-selected hotel customers to ensure ease and comprehension of the task, as well as to ensure reliable data collection methods. Average time for completing the entire survey was approximately 20 minutes and respondents did not indicate difficulty in comprehension.

Sampling Frame and Data Collection

The population of interest consisted of business and leisure travelers who stayed in economy, mid-range or upscale hotels. To obtain a representative sample (or as close to it as possible) we acquired 
from a third party vendor a reliable electronic mailing list of 4,000 potential respondents with residences scattered across the United States from a well-reputed marketing research company. The mailing list contained a sample of respondents balanced according to US census data validated by various demographics criteria. Each of the potential respondents received an email invitation to participate in the survey from the lead researcher. By participating in the survey, a respondent had the ability to participate in a raffle to win one of the ten gift certificates for $\$ 100$. From the initial list of potential respondents, approximately 2,500 chose to participate in the survey. Approximately 40 percent of the respondents answered negatively to the screening question (have you taken a business or leisure trip during the last one year which required a hotel stay?) and were not allowed to continue with the survey. At the conclusion of a three-week data collection period, a total of 930 respondents completed and returned the survey (each received a second email reminder). Since there was no indication of any response bias, the analysis presented in this paper is based on survey data collected from all the respondents.

\section{Analysis and Results}

\section{Sample Characteristics}

General sample characteristics and demographics are presented in Table II which shows that the respondent pool is very diverse in terms of age, gender, annual household income, and education level.

Table III shows a snapshot of travel frequency, the type of hotel room stayed in, and nightly room rate for the sample. A majority of the respondents had traveled in the last three months, taken 1-3 trips during the last 12 months, and paid nightly room rates between $\$ 40$ and 100 .

The sample was divided into two segments based on the following classification scheme.

Respondents who report that that more than 50 percent of their trips requiring hotel stays are business related are considered to be business travelers. A total of 169 respondents were classified as business travelers. Respondents who report that more than 50 percent of their trips requiring hotel stays are leisure related are considered to be leisure travelers. A total of 691 respondents were classified as leisure travelers. Those respondents who were split equally, 50 percent business and 50 percent leisure were categorized as business travelers. This resulted in a total of 239 business travelers and 691 leisure travelers. Next, we explain the results of the innovative hotel choice experiment. 
Table 1. Experimental constructs, attributes, and levels

\begin{tabular}{|c|c|c|}
\hline Constructs & Attributes & Levels \\
\hline \multirow[t]{3}{*}{ Hotel type } & Economy hotel & $\begin{array}{l}\text { (1) Motel } \\
\text { (2) Bed and breakfast inn } \\
\text { (3) Boutique hotel } \\
\text { (4) Standardized hotel affiliated/operated by recognized } \\
\text { chain }\end{array}$ \\
\hline & Midrange hotel & $\begin{array}{l}\text { (1) Bed and breakfast inn } \\
\text { (2) Independent boutique hotel } \\
\text { (3) Standardized hotel affiliated/operated by recognized } \\
\text { chain } \\
\text { (4) Boutique hotel operated by recognized chain }\end{array}$ \\
\hline & Upscale hotel & $\begin{array}{l}\text { (1) Independent boutique hotel } \\
\text { (2) Standardized hotel affiliated/operated by recognized } \\
\text { chain } \\
\text { (3) Boutique hotel operated by recognized chain } \\
\text { (4) Convention style hotel }\end{array}$ \\
\hline \multirow[t]{3}{*}{ Technology } & Internet access in room & $\begin{array}{l}\text { (1) Not available } \\
\text { (2) Available for } \$ 10 / \text { day } \\
\text { (3) Available for } \$ 5 / \text { day } \\
\text { (4) Available for free }\end{array}$ \\
\hline & Business center & $\begin{array}{l}\text { (1) Not available } \\
\text { (2) A centrally located business center } \\
\text { (3) Multiple business kiosks located throughout the facilities } \\
\text { (4) Mini-business center (printer, fax, etc.) available in room }\end{array}$ \\
\hline & Internet reservation & $\begin{array}{l}\text { (1) No } \\
\text { (2) Yes }\end{array}$ \\
\hline \multirow[t]{5}{*}{ Customization } & Pet policy & $\begin{array}{l}\text { (1) No pets } \\
\text { (2) Small pets }\end{array}$ \\
\hline & Flexible check in & $\begin{array}{l}\text { (1) No } \\
\text { (2) Yes }\end{array}$ \\
\hline & Room customization & $\begin{array}{l}\text { (1) No } \\
\text { (2) Yes }\end{array}$ \\
\hline & Childcare & $\begin{array}{l}\text { (1) Not available } \\
\text { (2) In-room nanny facility at extra charge } \\
\text { (3) In-room nanny facility + kids club (6-12 years) at extra } \\
\text { charge } \\
\text { (4) In-room nanny facility + kids club ( } 6-12 \text { years) + day } \\
\text { care ( } 6 \text { mo. or older) at extra charge }\end{array}$ \\
\hline & Kitchen & $\begin{array}{l}\text { (1) Available } \\
\text { (2) Coffee-maker available at no extra charge } \\
\text { (3) Coffee-maker available at no extra charge }+ \text { small } \\
\text { microwave }+ \text { fridge }+ \text { available at extra change } \\
\text { (4) Coffee-maker available at no extra charge }+ \text { small } \\
\text { microwave + fridge + available at extra change; and } \\
\text { selected units available with with full kitchenette at } \\
\text { extra charge }\end{array}$ \\
\hline
\end{tabular}

Innovative Hotel Choice Modeling Results

The primary analysis approach associated with DCA is the estimation of the MNL models based on a maximum likelihood estimation technique (Ben-Akiva and Lerman, 1991). Recall that each respondent had to evaluate eight choice sets, each containing two descriptions of hotels along with the 
option of not choosing either. Statistical details about MNL model estimation is described in extensive detail by Ben-Akiva and Lerman (1991) and Louviere et al. (2001).Amore applied description of DCA and MNL model estimation is provided in Verma et al. (2002) and Verma and Plaschka (2003). Louviere et al. (2001) and Ben-Akiva and Lerman (1991) recommend that when estimating MNL models, experimental variables can be "effects-coded" to accurately estimate the relative impact on respondents' choices. The estimated MNL model for this study was statistically significant at the 5 percent level.

Table IV shows the relative impact of each experimental attribute on hotel choice decisions. Recall that we are only focusing on the innovative attributes that were included in the original broader dataset. Therefore, all results presented ignore the non-innovative attributes that were also included in the study. The estimated $\beta$ weights for the innovative attributes are standardized to be between "zero" and "one" based on the highest and lowest part worth utility of an attribute. By transforming the data linearly, it is easy to compare and contrast the impacts of each attribute to one another. We estimated the relative main effect by subtracting the highest and lowest $\beta$ weights for a given attribute (Louviere et al., 2001). The main effects allow us to compare the overall impact of changing the levels of innovative attributes in hotel choice against each other.

Table 2. Demographic characteristics

\begin{tabular}{|c|c|c|c|c|}
\hline Characteristics & & $\begin{array}{c}\text { Total sample } \\
(930) \\
\text { (percent) }\end{array}$ & $\begin{array}{c}\text { Business segment } \\
\text { (239) } \\
\text { (percent) }\end{array}$ & $\begin{array}{c}\text { Leisure segment } \\
\text { (691) } \\
\text { (percent) }\end{array}$ \\
\hline \multicolumn{5}{|l|}{ Age } \\
\hline & $18-34$ years & 21.1 & 20.1 & 21.4 \\
\hline & $35-54$ years & 52.7 & 64.9 & 48.6 \\
\hline & $55+$ years & 26.2 & 15.1 & 30.0 \\
\hline \multicolumn{5}{|l|}{ Gender } \\
\hline & Male & 49.6 & 66.5 & 43.8 \\
\hline & Female & 50.4 & 33.5 & 56.2 \\
\hline Income & Under $\$ 25000$ & 125 & 81 & 140 \\
\hline & $\$ 25,001-75,000$ & 61.1 & $\begin{array}{r}0.1 \\
54.5\end{array}$ & $\begin{array}{l}14.0 \\
63.5\end{array}$ \\
\hline & $\$ 75,001-125,000$ & 19.3 & 23.9 & 17.6 \\
\hline & Over $\$ 125,001$ & 7.2 & 13.5 & 4.9 \\
\hline \multicolumn{5}{|l|}{ Education } \\
\hline & High school or less & 18.7 & 9.7 & 21.8 \\
\hline & Some college & 39.5 & 31.9 & 42.1 \\
\hline & College & 24.5 & 34.0 & 21.2 \\
\hline & College + & 17.4 & 24.4 & 14.9 \\
\hline
\end{tabular}


Table 3 Traveling Characteristics

\begin{tabular}{|c|c|c|c|}
\hline Characteristics & $\begin{array}{c}\text { Total sample (930) } \\
\text { (percent) }\end{array}$ & $\begin{array}{l}\text { Business segment (239) } \\
\text { (percent) }\end{array}$ & $\begin{array}{l}\text { Leisure segment (691) } \\
\text { (percent) }\end{array}$ \\
\hline \multicolumn{4}{|l|}{ Most recent hotel stay } \\
\hline Within the last month & 23.0 & 35.1 & 18.8 \\
\hline $\begin{array}{l}\text { Within the last } 1-3 \\
\text { months }\end{array}$ & 31.0 & 28.0 & 32.0 \\
\hline Within the last $4-6$ & & & \\
\hline $\begin{array}{l}\text { months } \\
\text { Within the last } 7-12\end{array}$ & 27.7 & 25.5 & 28.5 \\
\hline $\begin{array}{l}\text { months } \\
\text { Frequency of hotel } \\
\text { stays }\end{array}$ & 18.3 & 11.3 & 20.7 \\
\hline $1-3$ trips & 63.1 & 42.3 & 70.3 \\
\hline 4-6 trips & 24.2 & 23.4 & 24.5 \\
\hline $7-10$ trips & 7.2 & 17.2 & 3.8 \\
\hline $11-20$ trips & 2.5 & 7.1 & 0.9 \\
\hline 20 or more trips & 3.0 & 10.0 & 0.6 \\
\hline \multicolumn{4}{|l|}{ Type of hotel room } \\
\hline Standard room & 78.7 & 71.3 & 81.3 \\
\hline Suite & 17.9 & 25.7 & 15.3 \\
\hline Other & 3.4 & 3.0 & 3.5 \\
\hline \multicolumn{4}{|l|}{ Cost of nightly stay } \\
\hline Less than $\$ 60$ & 32.0 & 26.4 & 33.9 \\
\hline$\$ 61-100$ & 42.4 & 42.7 & 42.3 \\
\hline$\$ 101-150$ & 17.1 & 20.7 & 15.8 \\
\hline$\$ 151-200$ & 4.8 & 6.6 & 4.1 \\
\hline$\$ 201$ or more & 3.8 & 3.5 & 3.8 \\
\hline
\end{tabular}

The numerical results presented in Table IV are shown in Figures 2-5 to depict graphically the hotel choice patterns. It is important to reemphasize that the results provided are determined from the innovative constructs only; all other options were not included in the calculation of the estimated standardized b weights. Figure 2 shows the relative main effects of all experimental attributes and the relative impact of each of the levels. Among these three constructs, "hotel type" accounts for 61 percent of the relative weight, followed by "customization" with a relative weight of 27 and 12 percent from "technology". The main effect for each attribute was determined to give a more detailed insight into hotel choice criteria. For example, within the "customization" construct, the attributes with the smallest main effects are the option to customize room décor and the option of flexible check in/out. In addition, the availability of internet reservations has a small overall effect in comparison to the other technological attributes. A larger main effect for type of hotel became apparent when respondents were selecting a midrange to upscale hotel in comparison to an economy hotel. 
Table 4. Relative impact and relative main effects

\begin{tabular}{|c|c|c|c|c|c|c|}
\hline \multirow[b]{2}{*}{ Constructs } & \multirow[b]{2}{*}{ Attributes } & \multirow[b]{2}{*}{ Levels } & \multicolumn{2}{|c|}{ Business traveler } & \multicolumn{2}{|c|}{ Leisure traveler } \\
\hline & & & $\begin{array}{l}\text { Relative } \\
\text { impact }\end{array}$ & Main effects & $\begin{array}{l}\text { Relative } \\
\text { impact }\end{array}$ & Main effects \\
\hline \multirow[t]{13}{*}{ Hotel type } & \multirow[t]{4}{*}{ Economy hotel } & (1) Motel & 0.82 & \multirow[t]{4}{*}{0.57} & 0.57 & \multirow[t]{4}{*}{0.42} \\
\hline & & (2) Bed and breakfast inn & 0.29 & & 0.51 & \\
\hline & & (3) Boutique hotel & 0.25 & & 0.84 & \\
\hline & & $\begin{array}{l}\text { (4) Standardized hotel affiliated/operated by } \\
\text { recognized chain }\end{array}$ & 0.69 & & 0.42 & \\
\hline & \multirow[t]{4}{*}{ Midrange hotel } & (1) Bed and breakfast inn & 0.00 & \multirow[t]{3}{*}{1.00} & 0.00 & \multirow[t]{4}{*}{0.98} \\
\hline & & (2) Independent boutique hotel & 0.77 & & 0.58 & \\
\hline & & $\begin{array}{l}\text { (3) Standardized hotel affiliated/operated by } \\
\text { recognized chain }\end{array}$ & 1.00 & & 0.98 & \\
\hline & & (4) Boutique hotel operated by recognized chain & 0.28 & \multirow{6}{*}{0.89} & 0.77 & \\
\hline & \multirow[t]{5}{*}{ Upscale hotel } & (1) Independent boutique hotel & 0.67 & & 0.23 & \multirow[t]{5}{*}{0.77} \\
\hline & & (2) Standardized hotel affiliated/operated by & & & & \\
\hline & & reoognized chain & 0.94 & & 0.60 & \\
\hline & & (3) Boutique hotel operated by recognized chain & 0.05 & & 1.00 & \\
\hline & & (4) Convention style hotel & 0.39 & & 0.51 & \\
\hline \multirow[t]{10}{*}{ Technology } & \multirow[t]{4}{*}{ Internet access } & (1) Not available & 0.58 & \multirow[t]{4}{*}{0.25} & 0.66 & \multirow[t]{4}{*}{0.15} \\
\hline & & (2) Available for $\$ 10 /$ day & 0.43 & & 0.52 & \\
\hline & & (3) Available for $\$ 5 /$ day & 0.40 & & 0.51 & \\
\hline & & (4) Available for free & 0.65 & & 0.64 & \\
\hline & \multirow[t]{4}{*}{ Business center } & (1) Not available & 0.60 & \multirow[t]{4}{*}{0.15} & 0.48 & \multirow[t]{4}{*}{0.22} \\
\hline & & (2) A centrally located business center & 0.45 & & 0.49 & \\
\hline & & $\begin{array}{l}\text { (3) Multiple business k10sks located throughout the } \\
\text { facilities }\end{array}$ & 0.47 & & 0.70 & \\
\hline & & $\begin{array}{l}\text { (4) Mini-busines center (printer, fax, etc.) available } \\
\text { in room }\end{array}$ & 0.53 & & 0.65 & \\
\hline & \multirow[t]{2}{*}{ Internet reservation } & (1) No & 0.48 & \multirow[t]{2}{*}{0.07} & 0.55 & \multirow[t]{2}{*}{0.07} \\
\hline & & (2) Yes & 0.55 & & 0.62 & \\
\hline Customization & Pet policy & (1) No pets & 0.41 & 0.20 & 0.43 & 031 \\
\hline & & (2) Small pets & 0.61 & & 0.74 & \\
\hline & Flexible check in & (1) No & 0.50 & 0.13 & 0.49 & 0.18 \\
\hline & & (2) Yes & 0.52 & & 0.67 & \\
\hline & $\begin{array}{l}\text { Room } \\
\text { customization }\end{array}$ & (1) No & 0,45 & 0.13 & 0.60 & 0,03 \\
\hline & & $\begin{array}{l}\text { (1) No } \\
\text { (2) Yes }\end{array}$ & $\begin{array}{l}0.45 \\
0.58\end{array}$ & 0.13 & $\begin{array}{l}0.00 \\
0.57\end{array}$ & 0.03 \\
\hline & Childcare & (1) Not available & 0.51 & 0.25 & 0.64 & 0,40 \\
\hline & & $\begin{array}{l}\text { (2) In-room nanny facility at extra charge } \\
\text { (3) In-room nanny facility }+ \text { kids club (6-12 years) }\end{array}$ & 0.67 & & 0.32 & \\
\hline & & at extra charge & 0.45 & & 0.66 & \\
\hline & & $\begin{array}{l}\text { (4) In-room nanny facility + kids club }(6-12 \\
\text { years) + day care ( } 6 \text { mo. or older) at extra charge }\end{array}$ & 0.42 & & 0.72 & \\
\hline & Kitchen & (1) Available & 0.56 & 0.10 & 0.35 & 0.37 \\
\hline & & (2) Coffee-maker available at no extra charge & 0.55 & & 0.72 & \\
\hline & & $\begin{array}{l}\text { (3) Coffee-maker available at no extra } \\
\text { charge }+ \text { small microwave }+ \text { fridge }+ \text { available at }\end{array}$ & & & & \\
\hline & & extra change & 0.47 & & 0.62 & \\
\hline & & (4) Coffee-maker available at no extra & & & & \\
\hline & & $\begin{array}{l}\text { charge }+ \text { small microwave fridge }+ \text { available at } \\
\text { extra; and selected units available with full }\end{array}$ & & & & \\
\hline & & kitchenette at extra charge & 0.48 & & 0.64 & \\
\hline
\end{tabular}

Figure 3 shows the relative impact of each level of the "hotel type" attributes. For business travelers choosing an economy hotel, motels were the most preferred type of hotel. While those who were selecting a midrange to upscale hotel preferred standardized hotel chains with independently operated boutique hotels following close behind. In comparison, the most popular hotel type for leisure travelers selecting economy hotels were boutique hotels. In addition, leisure travelers choosing among 
upscale hotels most prefer boutique hotels operated by a recognized chain. Overall, boutique hotels were a strongly preferred option across both customer segments.
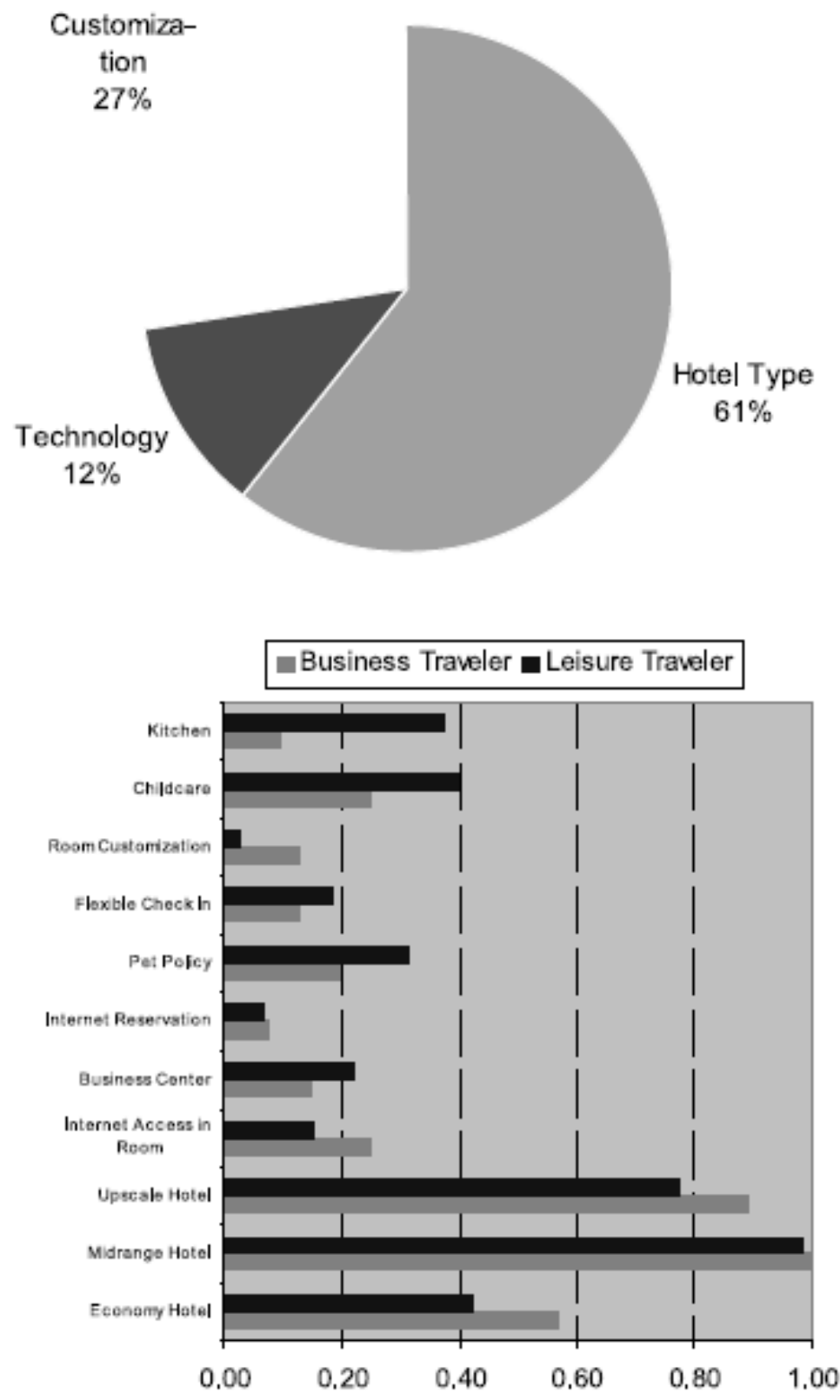

Figure 2. Relative main effects on constructs and determinant attributes

The relative main effects for the "technology" attributes are shown in Figure 4. For business travelers, providing internet access has the largest impact on hotel choice while for the leisure traveler it is the availability of a business center. While it may appear counterintuitive that leisure travelers' hotel choice is being influenced by a technological offering such as a business center, possible reasons for this 
perceived anomaly are described below: first, recall that these reported main effects are relative comparisons to one another. A business center may be the most preferred technological option, but when compared to other innovations such as childcare and in-room kitchen amenities it no longer has the largest impact. Second, leisure travelers may want a business center available to them because it provides benefits such as email checking, copying, package delivery, and other facilities which a leisure traveler might also value. Both segments ranked the option of booking hotel reservations via the internet as a low priority probably because internet reservations are no longer "order winners" but a necessary requirement. Furthermore, those respondents selecting amongst economy hotels, consistently weighted the availability of technological innovations more heavily than when selecting a midrange or upscale hotel. This would suggest that the hotel choice of travelers staying at economy hotels is swayed more from offerings of technological service innovations than travelers staying at midrange or upscale hotels.

Business Traveler

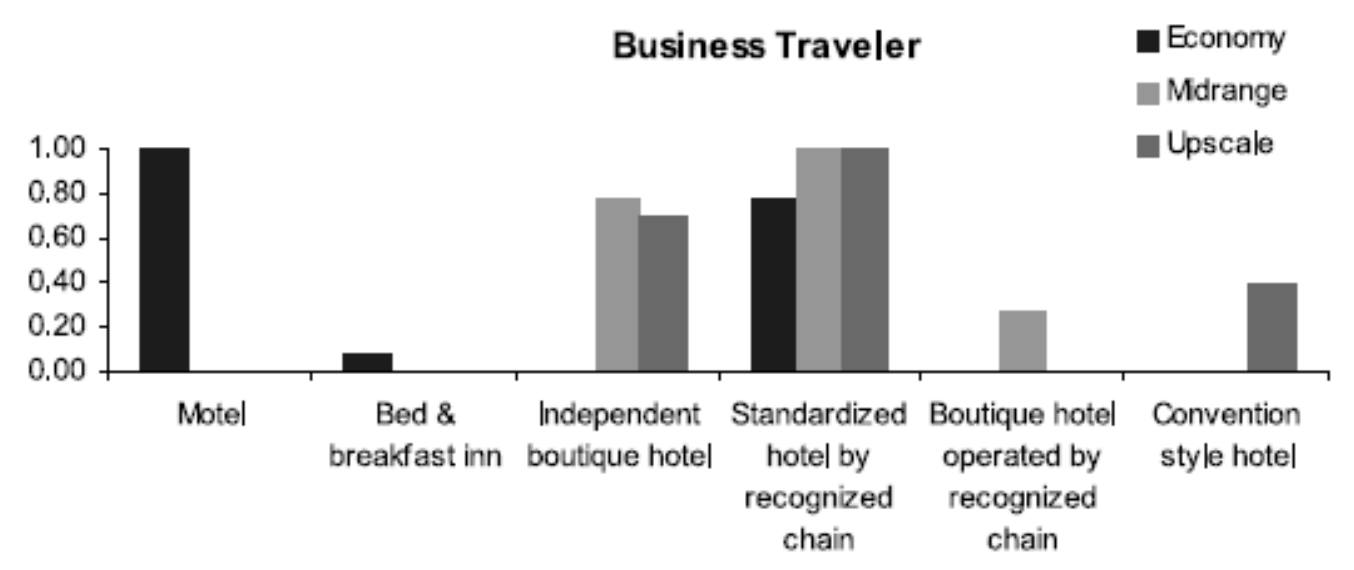

Motel

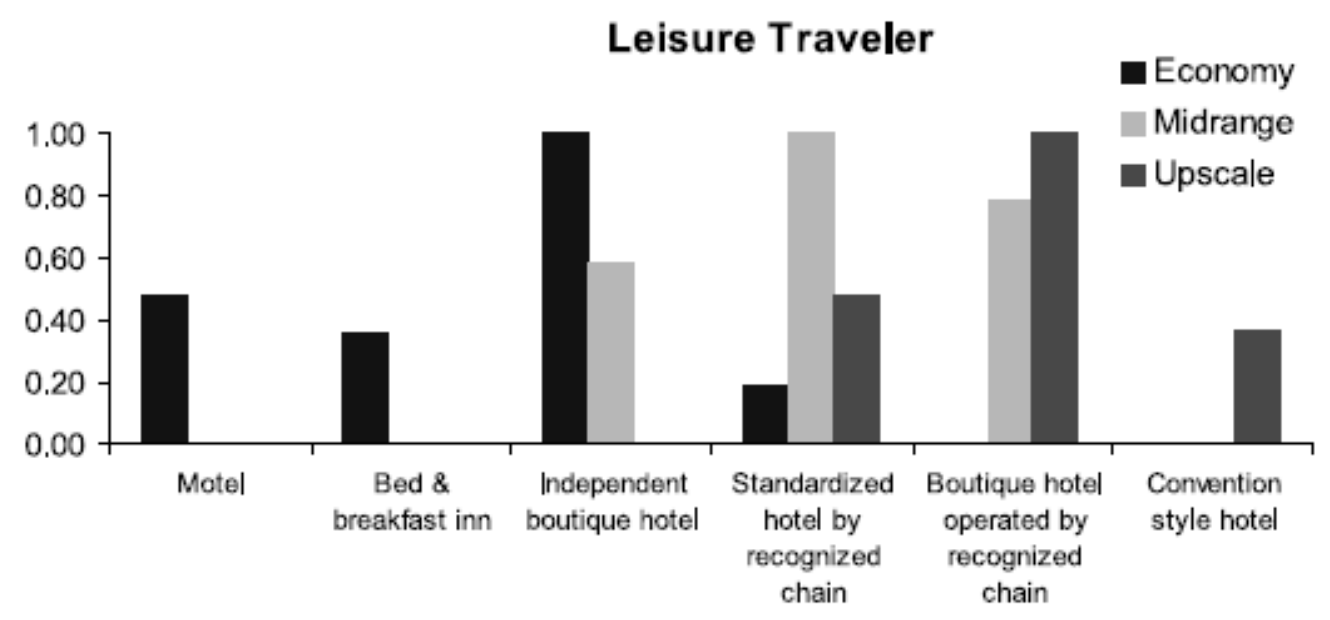

Figure 3. Relative impact of hotel attributes on hotel choice 
Figure 5 shows the main effects for the "customization" attributes. Across all hotel and traveler types, available childcare facilities, in-room kitchen facilities, and pet policies have the largest impact on hotel choice. Respondents deciding on economy hotels placed a greater emphasis on all the customized service options in comparison to the other types of hotels. Once again, implying that travelers choosing among economy hotels make their choices based on the innovative offerings the hotels provide.

The results shown in Figures 2-5 and Table IV have both academic and managerial implications. First, the results present the tradeoffs made by hotel guests. Secondly, by examining the tradeoffs made by hotel guests, in terms of innovative service offerings, we are able to enhance the design and development of a service concept. Lastly, by pinpointing which innovative attributes have an impact on hotel choice; managers will be able to judge how, operationally, they should deliver such innovative services.
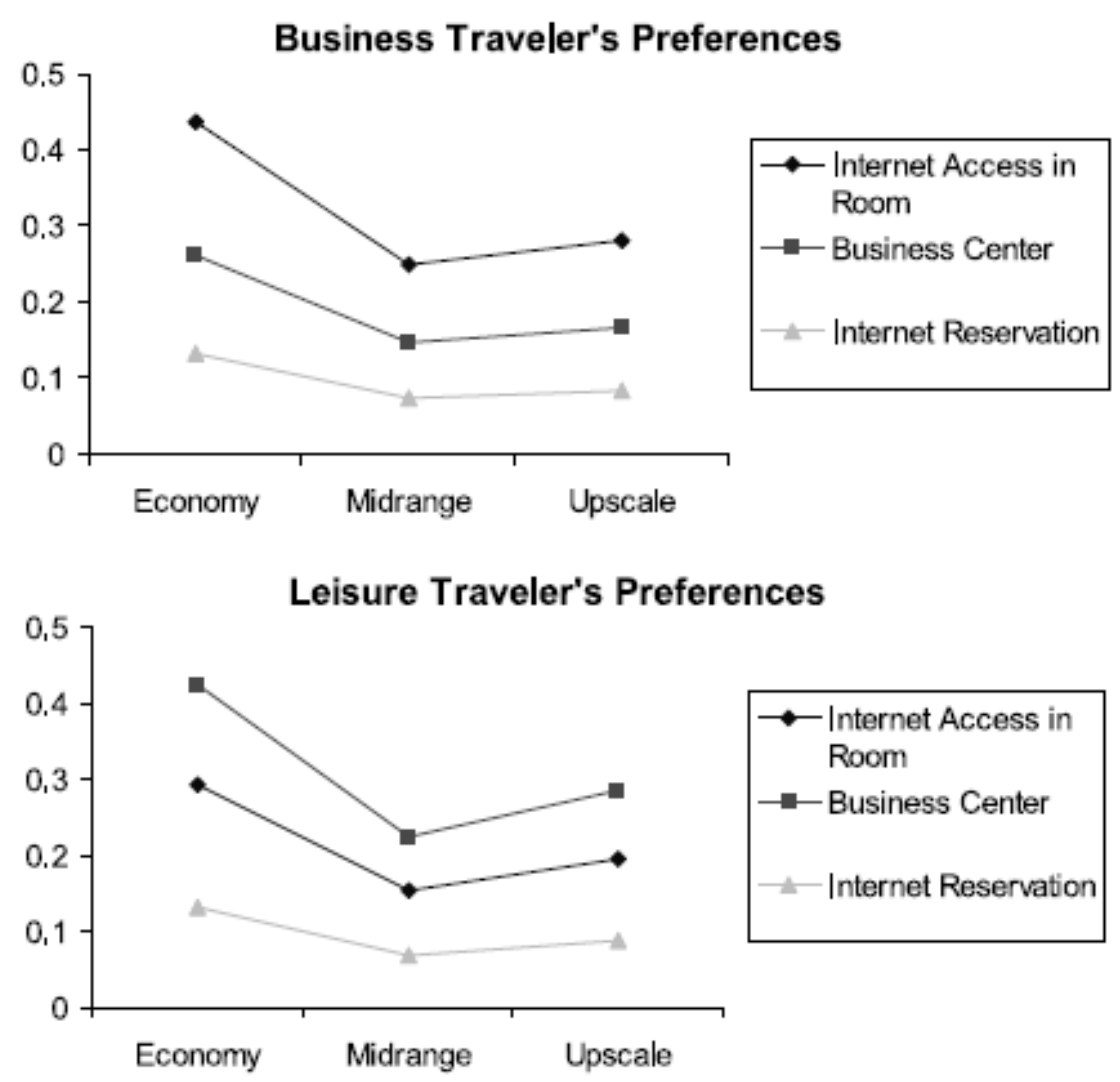

Figure 4. Main effects of technology attributes on hotel choice 

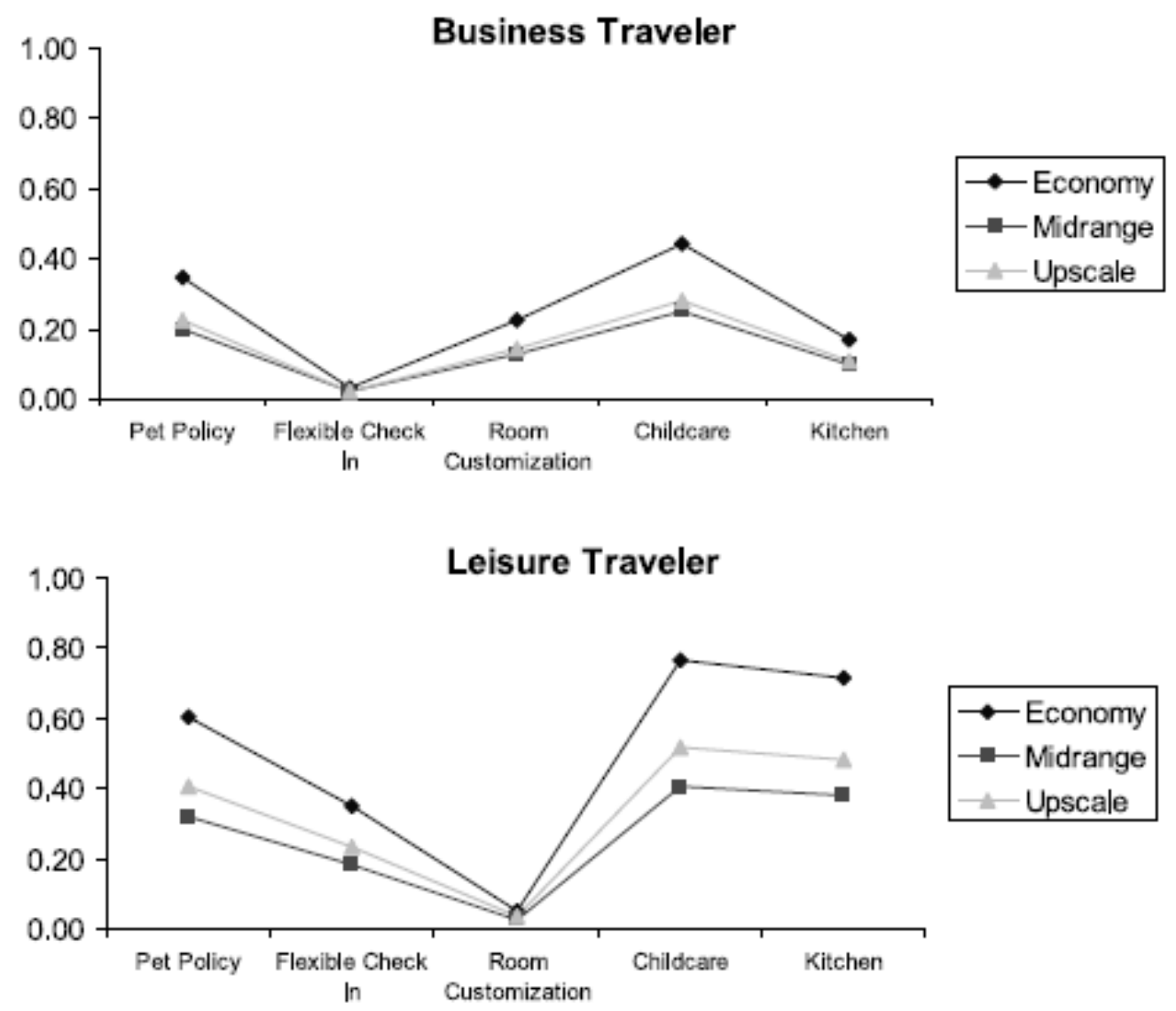

Figure 5. Main effects of customization attributes on hotel choice

\section{Discussion and Conclusions}

Past research and anecdotal evidence suggest that service innovation, in general, has a positive impact on customers' choice and can result in increased revenues for a firm. IBM's innovative service program is just one example of the financial benefits that can be realized from implementing service innovation. Our study, demonstrates the impact of including innovation within a hotel's service concept. The type of hotel has the largest impact for both business and leisure travelers' hotel choices. We also find service innovation to have a larger impact on guests who are selecting economy hotels in comparison to midrange or upscale hotels. Furthermore, innovative service amenities, such as technological improvements and customization features, have a stronger impact on leisure travelers' hotel choices in comparison to business travelers; while hotel type has a larger effect for business travelers' choices. Overall, we found across both customer segments that innovation does matter when selecting a hotel. 
Recalling the three broad categories of hotel innovation presented in our study - hotel type, technology, and customization we can infer the following results. First, hotel type contributed to the majority of hotel choice. In particular, business travelers' decisions were found to be guided more by hotel type when compared to leisure travelers; and midrange to upscale hotel selection were influenced more by hotel type than economy hotel selection. Second, the technology option, specifically the booking of hotel reservations via the internet, has the smallest impact on both business and leisure travelers' hotel choice. Third, the customization construct's greatest impacts came from available child care, pet accommodation, and the inclusion of in-room kitchen facilities.

Within each construct, tradeoffs were apparent for both business and leisure travelers. First, hotel type contributed to a significant portion of hotel guests' choices. The boutique hotel, the innovative option, stood out as a preferred choice among other more traditional alternatives. Independent boutique hotels were the second most popular hotel type for business travelers staying at midrange and upscale hotels and it is the most popular type for leisure travelers staying at economy hotels. Also, leisure travelers selecting from upscale hotels prefer boutique hotels operated by a recognized chain more than the other hotel options. A recognized chain boutique hotel was a secondary preference for leisure travelers selecting from mid-range hotels. Second, business travelers, across all hotel types, are more greatly influenced by the technological offering of in-room internet access. The availability of a business center was next in priority, followed by internet booking reservations. In contrast, leisure travelers, across all hotel types, are more greatly guided by the presence of a business center, followed by in-room internet access. Once again the smallest impact emanated from the internet reservation bookings option. Lastly, the preferred customization options included service offerings such as on-site child care, pet friendly policies, and in-room kitchen facilities rather than flexible check in/out and customized room décor. By examining the tradeoffs made by hotel guests, we are able to gain a better understanding of what types of innovative service offerings determine a traveler's hotel choice.

The customer tradeoffs we have identified play an important role in the design and development of a hotel's service concept. We have to remember that a service concept acts always as a mediator between the "what", customer needs, and the "how", operational capabilities of service design must be aligned. Additionally the study emphasizes the "what" for the service concept but does not specifically test the "how". However, a thorough understanding of customers' desires will allow experienced managers to more easily infer which operational capabilities are necessary to implement such innovations. For example, the popular hotel type option of a boutique hotel conjures up such 
operational questions as: what layout and facility changes would be necessary? What staff training would need to be conducted? What service amenities would be needed to constitute a boutique hotel to would be guests? Another example, in-room internet access, brings forth operational issues such as: what infrastructure costs are incurred from adding technological services? What price level would the hotel need to charge for the access or can it be complimentary? Would managers need to hire information technology staff for dealing with internet-related problems? Or would managers need to train the current staff to handle such problems? Similarly a flexible checking option might require implementation of a more complex hotel reservation and labor scheduling system. Therefore, while we have not statistically tested the influence of innovative service offerings on operational strategy formulation, we are still able to make inferences regarding operational issues which might arise from implementing various service innovations.

Numerous managerial implications can be drawn from our study. First and foremost, our study assists hotel managers in understanding what service innovations might have the greatest impact on potential guests' choices. This understanding will enhance the design and development of hotel service. In addition, it will focus manager's efforts around the innovations which are most important to guests. Through the provision of customer choice patterns, managers will be more adept at improving their operational planning and decision-making. Ultimately, the end result will be a better-devised operational strategy formulation that is sensitive to the preferences of customers. Furthermore, the results presented in this paper can be used to develop a decision-support model which can assist in conducting "what-if" type of analyses. The managers can evaluate the relative values and willingness to pay for each proposed service innovations prior to making huge investment of money and effort (Verma et al., 1999).

While our study provides a detailed outlook of the tradeoffs made by hotel travelers and the design and development of a hotel's service concept, there are limitations in our conclusions. For example, as in most studies, our data represents only one snapshot in time. This limits our ability to draw conclusions on the long-term impact of service innovations. In order to address this issue, a longitudinal study would be required to track and compare the impact of guests' choices over time. Also, our data are limited to the hotel industry and one geographic market, the US, which presents issues concerning the generalizability of the results. Studying hotels in a variety of countries, for example, would undoubtedly yield different service preference results. Thus, cross-cultural, horizontal and vertical industry sector studies would enhance the generalizability of the results. Despite the inherent limitations of our study, we have presented a solid first examination of the impact service innovation 
has on customer's choices and the operational issues which arise from implementing such service innovations.

In summary this paper offers both academic and managerial contributions through the examination of innovative service tradeoffs made by hotel guests. Our goal was to contribute to the service management literature by presenting an innovative-specific industry sector perspective when it comes to adding new services into the core service concept. We also presented a managerial tool for hotel managers to utilize when deciding which service innovations to implement. Finally the results can be used in formulating an operational strategy which aligns with hotel guests' values and preferences. By understanding the service innovation tradeoffs made by customers, a service concept can be designed more effectively yielding into a firm's much more profitable and sustainable operational strategy.

\section{References}

Agarwal, S., Erramilli, M.K. and Dev, C.S. (2003), “Market orientation and performance in service firms: role of innovation", The Journal of Services Marketing, Vol. 17 No. 1, pp. 68-82.

Anderson, J.C. and Narus, J.A. (1998), "Business marketing: understand what customers value", Harvard Business Review, Vol. 76 No. 6, pp. 53-65.

Ben-Akiva, M. and Lerman, S. (1991), Discrete Choice Analysis, MIT Press, Cambridge, MA.

Binkley, C. (1999), “Hotels: big chains finally discover virtues of 'boutique' hotels”, Wall Street Journal, p. 1, 7 January.

Binkley, C. (2003), "Wire storage racks, no box springs", Wall Street Journal, p. B.1, 8 October.

Chesbrough, H. (2004), "A failing grade for the innovation academy", Financial Times, available at: http://news.ft.com/home/us

Chittium, R. (2004), "Budget hotels to get a makeover: in bid for business travelers; major chains plan boutiques, area rugs and glassed-in showers", Wall Street Journal, p. D1, 8 June.

Danaher, P.J. (1997), “Using conjoint analysis to determine the relative importance of service attributes measured in customer satisfaction surveys", Journal of Retailing, Vol. 73 No. 2, pp. 235-60.

Edvardsson, B. and Olsson, J. (1996), "Key concepts for new service development", The Service Industries Journal, Vol. 16 No. 2, pp. 140-65.

Fitzgerald, M. (2005), "Research in development”, available at: www.technologyreview.com/

Goldstein, S.M., Johnston, R., Duffy, J. and Rao, J. (2002), "The service concept: the missing link in service design research?", Journal of Operations Management, Vol. 20 No. 2, pp. 121-34. 
Green, P. and Srinivasan, V. (1990), "Conjoint analysis in marketing: new developments with implications for research and practice", Journal of Marketing, Vol. 54 No. 4, pp. 3-19.

Han, J.K., Kim, N. and Srivastava, R. (1998), "Market orientation and organizational performance is innovation a missing link?", Journal of Marketing, Vol. 62 No. 4, pp. 30-45.

Karmarkar, U. (2004), "Will you survive the services revolution?”, Harvard Business Review, Vol. 82 No. 6, pp. $100-8$.

Kim, C. and Mauborgne, R. (2000), "Value innovation: the strategic logic of high growth", Harvard Business Review, Vol. 75 No. 1, pp. 102-13.

Louviere, J.J. and Timmermans, H. (1990), "Stated preference and choice models applied to recreation research: a review", Leisure Sciences, Vol. 12, pp. 9-32.

Louviere, J.J., Hensher, D.A. and Swait, J.D. (2001), Stated Preference Methods: Analysis and Application, Cambridge University Press, Cambridge.

McFadden, D. (1986), "The choice theory approach to market research", Journal of the Academy of Marketing Science, Vol. 5 No. 4, pp. 275-97.

Namasivayam, K., Enz, C.A. and Siguaw, J.A. (2000), "How wired are we?”, Cornell Hotel and Restaurant Administration Quarterly, Vol. 41 No. 6, pp. 40-8.

Olsen, M.D. and Connolly, D.J. (2000), “Experience-based travel”, Cornell Hotel and Restaurant Administration Quarterly, Vol. 41 No. 1, pp. 30-40.

Pullman, M.E. and Moore, W.L. (1999), “Optimal service design: integrating marketing and operations perspectives", International Journal of Service Industry Management, Vol. 10 No. 2, pp. 239-62.

Reid, R.D. and Sandler, M. (1992), "The use of technology to improve service quality", Cornell Hotel and Restaurant Administration Quarterly, Vol. 33 No. 3, pp. 68-73.

Schall, M. (2003), "Best practices in the assessment of hotel-guest attitudes", Cornell Hotel and Restaurant Administration Quarterly, Vol. 44 No. 2, pp. 51-65.

Skinner, W. (1974), "The focused factory", Harvard Business Review, Vol. 52 No. 3, pp. 113-21.

Stahl, M.J., Barnes, W.K., Gardial, S.F., Parr, W.C. and Woodruff, R.B. (1999), "Customer-value analysis helps hone strategy", Quality Progress, Vol. 32 No. 4, pp. 53-8.

Verma, R. and Plaschka, G. (2003), "The art and science of customer-choice modeling: reflections, advances, and managerial implications", Cornell Hotel and Restaurant Administration Quarterly, Vol. 44 Nos 5-6, pp. 155-65.

Verma, R., Thompson, G. and Louviere, J. (1999), “Configuring service operations based on customer needs and preferences", Journal of Service Research, Vol. 1 No. 3, pp. 262-74. 
Verma, R., Thompson, G., Moore, W. and Louviere, J. (2001), "Effective design of products/services: an approach based on integration of marketing and operations", Decision Sciences, Vol. 32 No. 1, pp. 165-93.

Verma, R., Plaschka, G. and Louviere, J. (2002), “Understanding customer choices: a key to successful management of hospitality services", Cornell Hotel and Restaurant Administration Quarterly, Vol. 43 No. 6, pp. 15-24.

Verma, R., Iqbal, Z. and Plaschka, G. (2004), "Choice drivers and switching inertia in e-financial services", California Management Review, Vol. 46 No. 4, pp. 43-68.

\section{This Article has been Cited by:}

1. Professor Bo Edvardsson and Professor Anders Gustafsson, Jie J. Zhang, Nitin Joglekar, Rohit Verma. 2014. Signaling eco-certification. Journal of Service Management 25:4, 494-511. [Abstract] [Full Text] [PDF]

2. Ching-Sung Lee, Yen-Cheng Chen, Pei-Ling Tsui, Tung-Han Yu. 2014. Examining the relations between open innovation climate and job satisfaction with a PLS path model. Quality \& Quantity 48:3, 1705-1722. [CrossRef]

3. Julia Nieves, Agustín Quintana, Javier Osorio. 2014. Knowledge-based resources and innovation in the hotel industry. International Journal of Hospitality Management 38, 65-73. [CrossRef]

4. Myra G. Sabir, Karl A. Pillemer. 2014. An intensely sympathetic awareness: Experiential similarity and cultural norms as means for gaining older African Americans' trust of scientific research. Journal of Aging Studies 29, 142-149. [CrossRef]

5. Dohee Kim, Richard R. Perdue. 2013. The effects of cognitive, affective, and sensory attributes on hotel choice. International Journal of Hospitality Management 35, 246-257. [CrossRef]

6. Daniel I. Prajogo, Christopher M. McDermott, Margaret A. McDermott. 2013. Innovation orientations and their effects on business performance: contrasting small- and mediumsized service firms. R\&D Management 43:5, 486-500. [CrossRef]

7. Breffni M Noone, Kelly A McGuire. 2013. Pricing in a social world: The influence of non-price information on hotel choice. Journal of Revenue and Pricing Management 12:5, 385-401. [CrossRef] 
8. Antonio Manuel Martínez-López, Alfonso A. Vargas-Sánchez. 2013. The Strategic Management Process and the Innovative Capacity of the Spanish Hotel Industry. Journal of Hospitality Marketing \& Management 22:6, 596-618. [CrossRef]

9. Juan Luis Nicolau, María Jesús Santa-María. 2013. The effect of innovation on hotel market value. International Journal of Hospitality Management 32, 71-79. [CrossRef]

10. Prakash Chathoth, Levent Altinay, Robert James Harrington, Fevzi Okumus, Eric S.W. Chan. 2013. Co-production versus co-creation: A process based continuum in the hotel service context. International Journal of Hospitality Management 32, 11-20. [CrossRef]

11. Rajesh Singh, Prof. Ravi Shankar, Rania A.M. Shamah. 2012. Innovation within green service supply chains for a value creation. Journal of Modelling in Management 7:3, 357-374. [Abstract] [Full Text] [PDF]

12. Rohit Verma, Anders Gustafsson, Per Kristensson, Lars Witell. 2012. Customer co-creation in service innovation: a matter of communication?. Journal of Service Management 23:3, 311327. [Abstract] [Full Text] [PDF]

13. Vinnie Jauhari, Meghna Rishi, Vinnie Jauhari, Meghna Rishi. 2012. Challenges faced by the hospitality industry in India: an introduction. Worldwide Hospitality and Tourism Themes 4:2, 110-117. [Abstract] [Full Text] [PDF]

14. Anthony Brien, Nazmun Ratna, Lyn Boddington. 2012. Is Organizational Social Capital Crucial for Productivity Growth? An Exploration of "Trust" within Luxury Hotels in New Zealand. Journal of Human Resources in Hospitality \& Tourism 11:2, 123-145. [CrossRef]

15. Hashim Fadzil Ariffin, Raja Puteri Saadiah Raja Abdullah, Mohamad Fahmi Bibon. 2012. Assessing Service Quality: Prayer's Perspective. Procedia - Social and Behavioral Sciences 36, 511-519. [CrossRef] Downloaded by Cornell University Library At 09:10 24 October 2014 (PT)

16. Song Chang, Yaping Gong, Cass Shum. 2011. Promoting innovation in hospitality companies through human resource management practices. International Journal of Hospitality Management 30:4, 812-818. [CrossRef]

17. Jayne M. Rogerson. 2011. The Limited Service Hotel in South Africa: The Growth of City Lodge. Urban Forum 22:4, 343-361. [CrossRef]

18. Yung-Ho Chiu, Chin-Wei Huang. 2011. Evaluating the optimal occupancy rate, operational efficiency, and profitability efficiency of Taiwan's international tourist hotels. The Service Industries Journal 31:13, 2145-2162. [CrossRef] 
19. Anil Bilgihan, Fevzi Okumus, Khaldoon "Khal” Nusair, David Joon-Wuk Kwun. 2011. Information technology applications and competitive advantage in hotel companies. Journal of Hospitality and Tourism Technology 2:2, 139-153. [Abstract] [Full Text] [PDF]

20. Pim Den Hertog, Faïz Gallouj, Jeroen Segers. 2011. Measuring innovation in a 'low-tech' service industry: the case of the Dutch hospitality industry. The Service Industries Journal 31:9, 1429-1449. [CrossRef]

21. Rob Law, Billy Bai, Anne P. Crick, Andrew Spencer. 2011. Hospitality quality: new directions and new challenges. International Journal of Contemporary Hospitality Management 23:4, 463-478. [Abstract] [Full Text] [PDF]

22. Ching-Shu Su. 2011. The role of service innovation and customer experience in ethnic restaurants. The Service Industries Journal 31:3, 425-440. [CrossRef]

23. Jayne M. Rogerson. 2010. The Boutique Hotel Industry in South Africa: Definition, Scope, and Organization. Urban Forum 21:4, 425-439. [CrossRef]

24. TOR HELGE AAS, PER E. PEDERSEN. 2010. THE FIRM-LEVEL EFFECTS OF SERVICE INNOVATION: A LITERATURE REVIEW. International Journal of Innovation Management 14:05, 759-794. [CrossRef]

25. Michael C. Ottenbacher, Robert J. Harrington. 2010. Strategies for achieving success for innovative versus incremental new services. Journal of Services Marketing 24:1, 3-15. [Abstract] [Full Text] [PDF]

26. Anne-Mette Hjalager. 2010. A review of innovation research in tourism. Tourism Management 31:1, 1-12. [CrossRef]

27. Hermann Frank, Manfred Lueger, Christian Korunka. 2010. Innovative Kleinunternehmen: Eine qualitative Systemanalyse. ZfKE - Zeitschrift für KMU und Entrepreneurship 58:1, 1-30. [CrossRef]

28. Başar Öztayşi, Serdar Baysan, Fatma Akpinar. 2009. Radio frequency identification (RFID) in hospitality. Technovation 29:9, 618-624. [CrossRef]

29. Ekaterina V. Karniouchina, William L. Moore, Bo van der Rhee, Rohit Verma. 2009. Issues in the use of ratings-based versus choice-based conjoint analysis in operations management research. European Journal of Operational Research 197:1, 340-348. [CrossRef]

30. Meng-Lei Monica Hu, Jeou-Shyan Horng, Yu-Hua Christine Sun. 2009. Hospitality teams: Knowledge sharing and service innovation performance. Tourism Management 30:1, 41-50. [CrossRef] 
31. Nick Johns, Richard Teare, Mandy Aggett. 2007. What has influenced growth in the UK's boutique hotel sector?. International Journal of Contemporary Hospitality Management 19:2, 169-177. [Abstract] [Full Text] [PDF]

32. Compilation of References 0-0. [CrossRef]

33. Yudi FernandoService Innovation along the Chain of Service Process in Airline Business 185201. [CrossRef]

34. Hospitality Innovations in the Emerging Experience Economy: 0-0. [CrossRef] 